\title{
Effect of weaning age on growth performance, feed efficiency, nutrient digestibility and blood-biochemical parameters in Droughtmaster crossbred beef calves
}

\author{
Hui Tao ${ }^{1, a}$, Feng Guo ${ }^{1, a}$, Yan Tu', Bing-Wen Si ${ }^{1}$, Yu-Chuan Xing ${ }^{2}$, De-Jun Huang ${ }^{2}$, and Qi-Yu Diao ${ }^{1, *}$
}

\begin{abstract}
* Corresponding Author: Qi-Yu Diao Tel: +86-13910616460, Fax: +86-01062169105, E-mail: diaoqiyu@caas.cn
\end{abstract}

'Feed Research Institute, Chinese Academy of Agricultural Sciences, Key Laboratory of Feed Biotechnology of the Ministry of Agriculture, Beijing 10081, China

2 Herbivorous Animal Husbandry Research Institute, Chongqing Academy of Animal Husbandry,

Chongqing 404100, China

a These authors contributed equally to this research and should be considered co-first authors.

ORCID

Hui Tao

https://orcid.org/0000-0003-3981-9251

Feng Guo

https://orcid.org/0000-0003-0654-4933 Yan Tu

https://orcid.org/0000-0002-4324-6188

Bing-Wen Si

https://orcid.org/0000-0001-5050-7078

Yu-Chuan Xing

https://orcid.org/0000-0001-8666-506X

De-Jun Huang

https://orcid.org/0000-0002-2327-9257

Qi-Yu Diao

https://orcid.org/0000-0002-8037-1471

Submitted Jul 13, 2017; Revised Sept 13, 2017; Accepted Nov 1, 2017
Objective: The objective of this study was to determine the effect of weaning age on intake, performance, nutrition metabolism and serum parameters of beef calves.

Methods: Sixty Droughtmaster crossbred calves were assigned to 5 groups with 12 calves in each group. The calves in control group remained with the dams till the 22-week age, while the calves weaned at $28 \mathrm{~d}(4 \mathrm{wk}), 42 \mathrm{~d}(6 \mathrm{wk}), 56 \mathrm{~d}(8 \mathrm{wk})$, and $70 \mathrm{~d}(10 \mathrm{wk})$ of age were sent to group $4 \mathrm{wk}$, group $6 \mathrm{wk}$, group $8 \mathrm{wk}$, and group $10 \mathrm{wk}$, respectively, and then were fed on milk replacer till the 22-week age. Feed intake and body weight and size were record and blood metabolites were measured. And 24 calves of them (6 in each group) were picked randomly for digestion and metabolism trail. Feed, feces and urine sample were taken and measured.

Results: Dry matter intake of calves in group 4 wk was significantly lower than those in the remaining groups from wk 17 to $22(\mathrm{p}<0.05)$. Feed efficiency of the calves was higher in groups $4 \mathrm{wk}$ and $6 \mathrm{wk}$ than those in groups $8 \mathrm{wk}$ and $10 \mathrm{wk}$ from 11 to $13 \mathrm{wk}(\mathrm{p}<0.05)$, and calves had higher feed efficiency in group $4 \mathrm{wk}$, group $6 \mathrm{wk}$, and group $8 \mathrm{wk}$ than those in group $10 \mathrm{wk}$ from wk 14 to wk 22 . Calves in group $4 \mathrm{wk}$ and $6 \mathrm{wk}$ had lower body weight than group $8 \mathrm{wk}$ and group $10 \mathrm{wk}$ and control group at 10 -week age $(\mathrm{p}<0.05)$ and 13 -week age $(\mathrm{p}<0.05)$, and calves in group $6 \mathrm{wk}$ had no significant difference in body weight with control group, group $8 \mathrm{wk}$ and $10 \mathrm{wk}(\mathrm{p}>0.05)$ but was higher than that of group $4 \mathrm{wk}(\mathrm{p}<0.05)$. Calves in group $6 \mathrm{wk}$ had higher final body weight and total gain than group $4 \mathrm{wk}$, but no difference of total gain with that of groups $8 \mathrm{wk}, 10 \mathrm{wk}$, and control group. And weaning calves at 6-week age brought higher feed efficiency and average daily gain from wk 14 to wk 22, and higher dry matter and organic matter digestibility at $21 \mathrm{wk}$.

Conclusion: It is concluded that the weaning of calves at 6 weeks of age gave positive results.

Keywords: Weaning Age; Growth Performance; Feed Efficiency; Beef Calves

\section{INTRODUCTION}

It is generally recognized that calves weaned earlier underperform compared to those in conventional weaning period. Beef calves are the products produced in the beef feedlot compared to a dairy, and lactating beef cows need to accomplish three fundamental things related to nutrition: produce sufficient milk to maintain calf growth, achieve target body condition scores of their calves and conceive again for next calving. Research on early weaning has been more popular in recent years for a variety of reasons including better utilization of limited feed, a good means to keep young cows in good condition and improve reproduction in their first few years [1], and alter growth of beef calves to enhance carcass characteristics [2-5]. It was reported that weaning calves before the start of the breeding season improved reproductive performance [6,7]. Early weaning of calves allows cows to have better weight 
recovery in the post-weaning and breeding periods, compared to cows with calves suckled until conventional weaning age, cows with early weaning calves consequently have better pregnancy rate. Weaning at 3, 4, 5, or 6 weeks of age had no influence on growth performance and feed efficiency in dairy calves [8], and early weaning calves at $80 \mathrm{~d}$ won't impair a heifer to be a replacement female as early weaned heifers have similar or greater reproductive success than heifers normal weaned at $215 \mathrm{~d}$ [9]. In the present study, we focused on the bull beef calves, and weaned them at age of 4, 6, 8, and 10 weeks to elucidate the effect of weaning age on calves' growth performance, feed efficiency, nutrient digestibility, and serum parameters of calves and explore the optimal time for calves to feed on milk replacer (MR).

\section{MATERIALS AND METHODS}

The experimental protocol was approved by the Chinese Academy of Agricultural Sciences Animal Ethics Committee, which was performed in accordance with animal welfare practices and procedures followed the Guidelines for Experimental Animal of the Ministry of Science and Technology (2006, Beijing, China).

\section{Animals and feeding regimens}

Droughtmasters can withstand a tropical environment, and they have been brought to Southern China since 1970s to improve the local cattle breed's ability to deal with a harsh environment. In the present experiment, 60 Droughtmaster $\times$ local yellow cattle crossbred newly born calves (with in $\pm 3 \mathrm{~d}$ ) were weighed, and left suckling on dams for adequate colostrum for the first 3 days. Then they were divided into 5 groups randomly, and calves in control group remained with the dams till they were weaned at 22 weeks of age. The rest of the calves were sent to the calf shelters with bedding at age of 28 days in group $4 \mathrm{wk}, 42$ days in group $6 \mathrm{wk}, 56$ days in group $8 \mathrm{wk}$, and 70 days in group $10 \mathrm{wk}$, then they were offered MR instead of dams milk at $1.2 \%$ of body weight (BW) to 10 weeks of age with the feeding amount of MR decreasing gradually until weaning at 13 weeks of age. To make the MR, the water was boiled then cooled it till $50^{\circ} \mathrm{C}$, then blended with $\mathrm{MR}$ at the rate of $100 \mathrm{~g}$ of as-fed powder into a volume of $600 \mathrm{~mL}$ with warm water. The MR was fed to calves at $39^{\circ} \mathrm{C}$ twice a day, 08:00 am and 5:00 pm. After every usage, the bottles equipped with rubber nipples were cleaned and dried. Calves had unrestricted access to water during the experimental period and were offered starter and forage ad libitum from 29 days of age till the experiment was finished. The ingredients and composition of starter and MR were shown in Table 1 . And 24 calves in group $4 \mathrm{wk}, 6 \mathrm{wk}, 8 \mathrm{wk}$, and $10 \mathrm{wk}$ with 6 calves in each group were picked randomly for digestion experiment at d 80 to 90 and d 140 to 150 , separately.
Table 1. Composition and analysis of a calf starter on DM basis

\begin{tabular}{lcc}
\hline Item & Starter & Milk replacer \\
\hline Ingredients & & \\
Corn & 62.4 & - \\
Soybean meal & 22.0 & - \\
Wheat bran & 11.0 & - \\
$\mathrm{NaCl}$ & 1.0 & - \\
CaHPO $_{4}$ & 1.3 & - \\
Limestone & 1.3 & - \\
1\% premix & 1.0 & - \\
Total & 100 & - \\
Nutrient compositions ${ }^{2)}$ & & \\
DM (\%) & 87.3 & 93.22 \\
GE (MJ/kg) & 15.62 & 19.21 \\
EE (\%) & 3.16 & 13.10 \\
CP (\%) & 16.47 & 23.94 \\
Ash (\%) & 6.50 & 6.07 \\
Ca (\%) & 0.86 & 0.85 \\
P (\%) & 0.63 & 0.61 \\
\hline
\end{tabular}

$\mathrm{DM}$, dry matter; $\mathrm{GE}$, general energy; $\mathrm{EE}$, ether extract; $\mathrm{CP}$, crude protein.

1) Premix provided Vit A 15,000 IU; Vit D 5,000 IU; Vit E 50 mg; Fe 90 mg; Cu 12.5 mg; Mn 60 mg; Zn 100 mg; Se 0.3 mg; I 1.0 mg; Co 0.5 mg per kg of pellet diet.

${ }^{2)}$ Nutrient composition are all measured values.

\section{Sampling and analysis}

Feeding amounts of MR, starter, forage and the refusals were recorded daily. Body length, wither height, heart girth, abdominal circumference and hip width were measured at birth and final day of the experiment according to [10].

The composited dietary samples, including $\mathrm{MR}$, starter and forage were collected every 2 weeks in the experimental period. The samples were analyzed for dry matter (DM, method 930.15), ash (method 924.05), ether extract (EE, method 920.85) according AOAC [11], and the difference between $\mathrm{DM}$ and ash content was organic matter $(\mathrm{OM})$. Crude protein (CP) was calculated as $6.25 \times \mathrm{N}$, which was measured with Kjeldahl digestion and selenium as a catalyst [2]. Neutral detergent fiber and acid detergent fiber was determined according to the method reported by [12] and [13] respectively.

The calves suckled on dams before they were moved to MR, therefore the dry matter intake (DMI) of the calves remaining with dams could not be calculated precisely, and calculations started at $\mathrm{d} 71$ when the calves in the 4 groups were weaned off milk totally. Fecal samples were taken for 4 days during the 2 periods in the nutrients digestion trial and were frozen daily and combined on an equal wet weight basis to be subsampled for further analysis. The concentrations of nutrients in the feed, feed intake and in feces were used to estimate apparent digestibility.

Blood samples were collected by coccygeal venipuncture before morning feeding on 70, 91, and $154 \mathrm{~d}$, and the serum was separated by centrifugation at $3,000 \mathrm{rpm} / \mathrm{min}$ for 10 minutes and then stored at $-20^{\circ} \mathrm{C}$ for further analysis. Blood 
glucose, urea nitrogen, total cholesterol, albumin, globulin and alkaline phosphatase (ALP) were analyzed by a biochemical auto-analyzer (Hitachi automatic biochemical analyzer 7600, Tokyo, Japan) using commercially available kits: glucose, and urea nitrogen, total protein, albumin, globulin, ALP and immunoglobulin $\mathrm{G}$ (IgG), IgM, and IgA according to the manufacturer's instructions (Biosino Polytron Technologies Inc, Beijing, China).

\section{Statistical analysis}

The data were analyzed using general liner model procedures of SAS (SAS Systems, SAS Institute Inc., Cary NC, USA) with random calf effect, the fixed factor of age and treatment, and adjusted means were compared with least significant difference. Significance was set at $\mathrm{p} \leq 0.05$, and the data were expressed as average value and accompanied by standard error of the means.

\section{RESULTS}

\section{Intake}

Starter intake of calves were greater in group 4 wk than that in the rest groups at wk 6 and wk $7(\mathrm{p}<0.05)$, and were higher in group $6 \mathrm{wk}$, group $8 \mathrm{wk}, 10 \mathrm{wk}$, and control group than calves in group $4 \mathrm{wk}$ from wk 18 to wk $22(\mathrm{p}<0.05)$ (Figure 1$)$. Roughage intake had no significant differences at the first 9 weeks (wk 5 to wk 13) and last 2 weeks (wk 21 to wk 22), and calves in group $4 \mathrm{wk}, 6 \mathrm{wk}, 8 \mathrm{wk}$, and $10 \mathrm{wk}$ had higher roughage intake than that in control group $(\mathrm{p}<0.05)$ from wk 14 to wk 21 (Figure 2). DMI had no significant difference between the groups from wk 11 to wk 14 and at wk 16 (p>0.05), and it decreased in the calves of group $4 \mathrm{wk}$ and group $6 \mathrm{wk}$ at $\mathrm{wk}$ 14 but increased thereafter. And the DMI of calves in group $8 \mathrm{wk}$ was higher than that in group $4 \mathrm{wk}, 6 \mathrm{wk}$, and $10 \mathrm{wk}$ at wk $16(\mathrm{p}<0.05)$, and DMI of calves in group $4 \mathrm{wk}$ was lower than that in group $6 \mathrm{wk}$, group $8 \mathrm{wk}$ and group $10 \mathrm{wk}$ from wk 17 to wk $22(\mathrm{p}<0.05)$ (Figure 3$)$.

Weight gain, body size measurements and feed efficiency Body weight of calves at age of $10 \mathrm{wk}$ and $13 \mathrm{wk}$ in group $4 \mathrm{wk}$ and group 6 wk was lower than that in the rest of the groups $(\mathrm{p}<0.05)$, but calves in group $6 \mathrm{wk}$ had no significant difference in BW with those in control group, group $8 \mathrm{wk}$ and group $10 \mathrm{wk}$ at age of $22 \mathrm{wk}(\mathrm{p}>0.05)$, shown in Table 2. Average daily gain $(\mathrm{ADG})$ of calves in group $6 \mathrm{wk}$ was significantly lower than that in control group, group $8 \mathrm{wk}$ and group 10 wk from wk 1 to wk 10, but had no significant difference with that in control group, group $4 \mathrm{wk}$, group $8 \mathrm{wk}$, and group 10 wk from wk 11 to wk 13 ( $>>0.05)$, and was significantly higher than that in control group, group $4 \mathrm{wk}$, group $8 \mathrm{wk}$, and group $10 \mathrm{wk}$ from wk 14 to wk $22(\mathrm{p}<0.05)$. Total gain of calves in group $4 \mathrm{wk}(92.15 \pm 2.30 \mathrm{~kg})$ was significantly lower than that in control group $(99.63 \pm 2.30 \mathrm{~kg})$, group $6 \mathrm{wk}(102.50 \pm 2.30 \mathrm{~kg})$, group $8 \mathrm{wk}(101.08 \pm 2.30 \mathrm{~kg})$ and group $10 \mathrm{wk}(100.17 \pm 2.30$

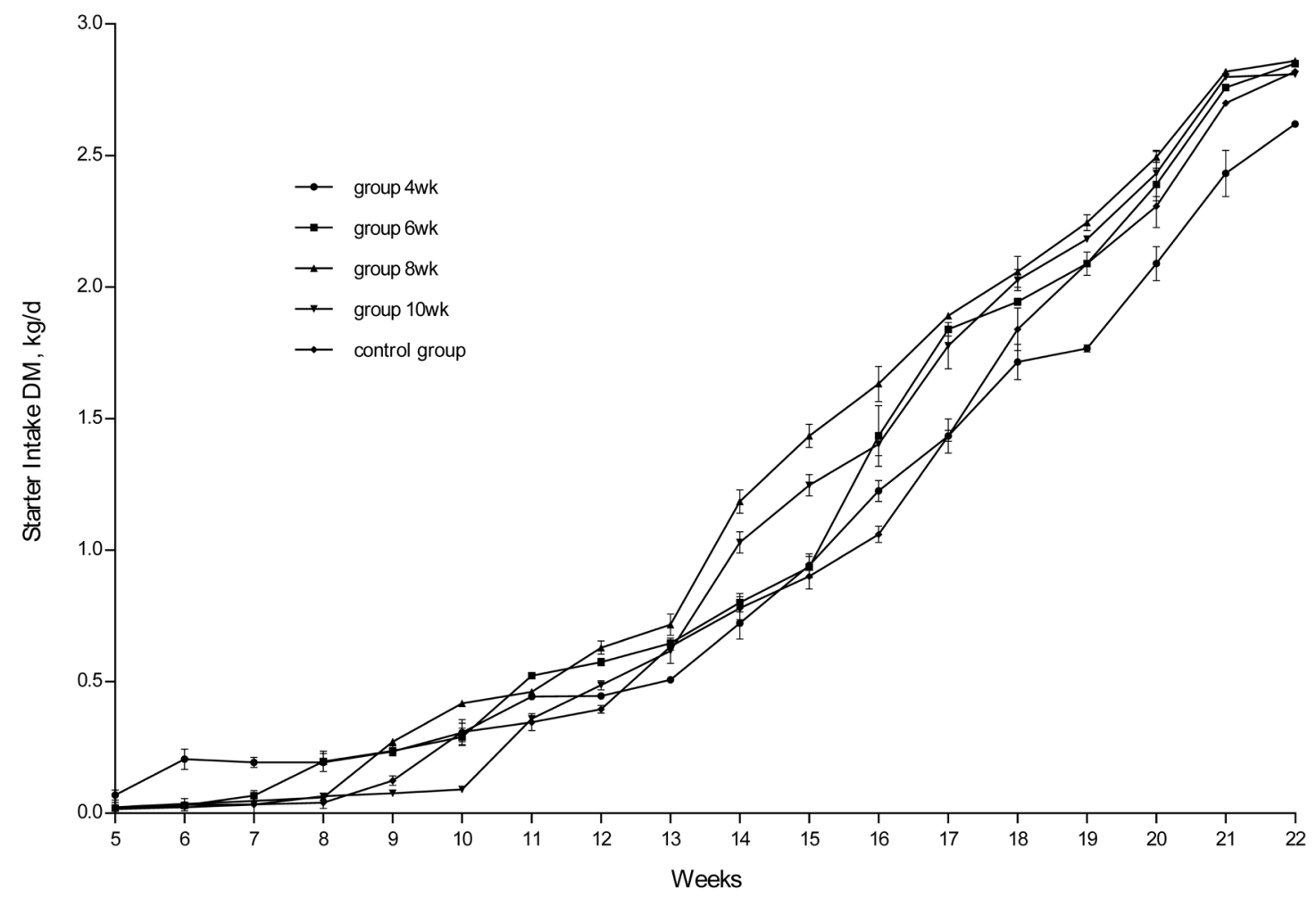

Figure 1. Effect of weaning age on starter intake of calves from 5 wk to 22 wk shown as means \pm standard errors. 


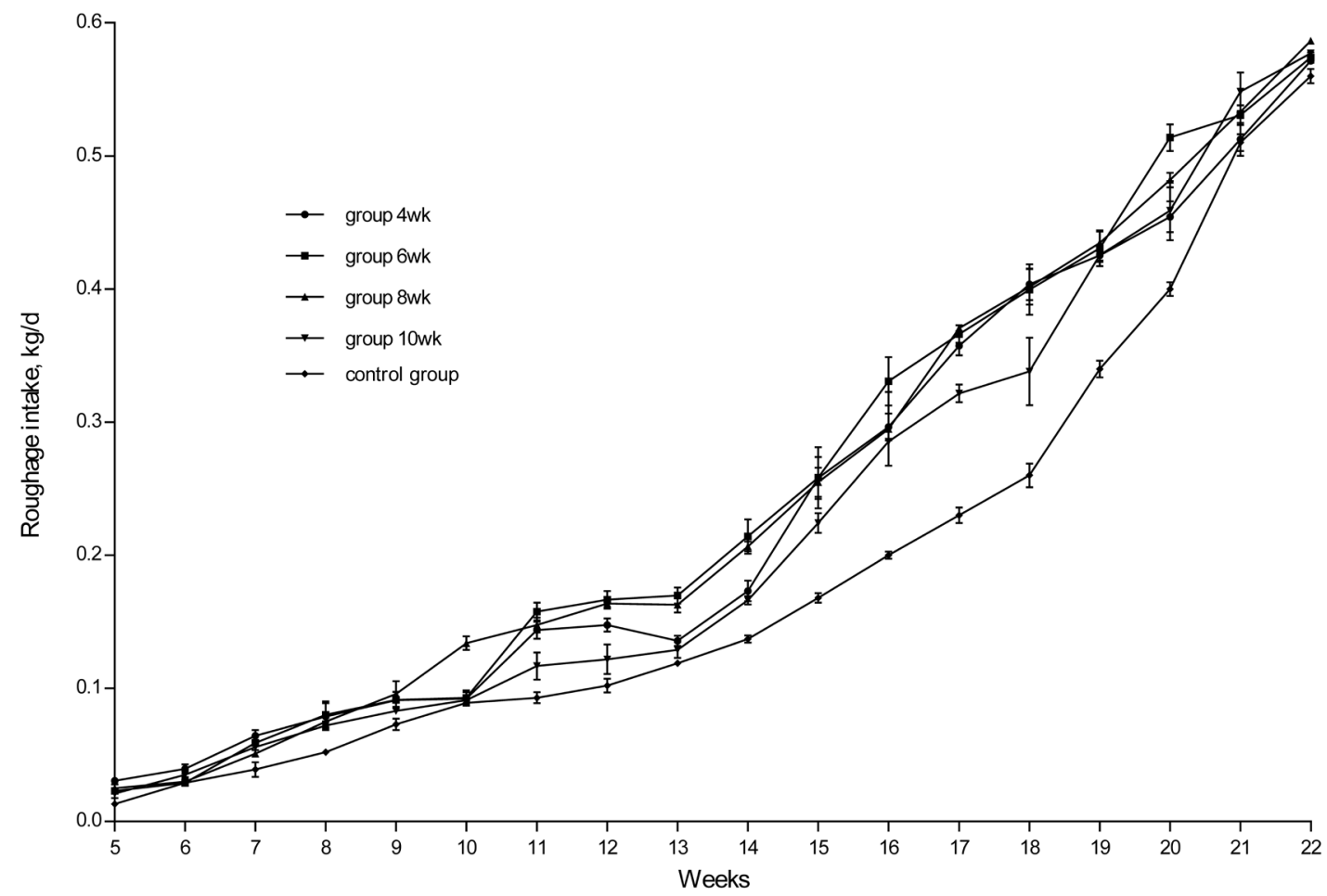

Figure 2. Effect of weaning age on roughage intake of calves from 5 wk to 22 wk shown as means \pm standard errors.

$\mathrm{kg})(\mathrm{p}<0.05)$. Final wither height of calves in group $6 \mathrm{wk}$ and group $8 \mathrm{wk}$ had no significant difference with the calves in control group, but higher than the calves in group $4 \mathrm{wk}$ and group $6 \mathrm{wk}$, and total gain of wither height of calves in group $10 \mathrm{wk}$ was higher than the calves in control group, but calves in group $4 \mathrm{wk}$ and group $6 \mathrm{wk}$ was lower than the calves in control group. Final hip width of calves in group $4 \mathrm{wk}, 6 \mathrm{wk}$, and $8 \mathrm{wk}$ had no significant difference with that of calves in control group, but was significantly higher than that in group $10 \mathrm{wk}$, and total gain of hip width of calves in group $4 \mathrm{wk}, 6 \mathrm{wk}$, and $8 \mathrm{wk}$ were significantly higher than the calves in group $10 \mathrm{wk}$ and control group. Feed efficiency of calves was higher in group $4 \mathrm{wk}$ and group $6 \mathrm{wk}$ than those in group $8 \mathrm{wk}$ and group $10 \mathrm{wk}$ from wk 11 to wk 13, and calves had higher feed efficiency in group $4 \mathrm{wk}$, group $6 \mathrm{wk}$, and group $8 \mathrm{wk}$ than those in group 10 wk from wk 14 to wk 22 (Table 2).

\section{Nutrients digestibility}

In the first period, there were no differences of digestibility of $\mathrm{DM}, \mathrm{OM}, \mathrm{CP}$, fat, $\mathrm{P}$, and Ca between calves in 4 groups ( $\mathrm{p}>$

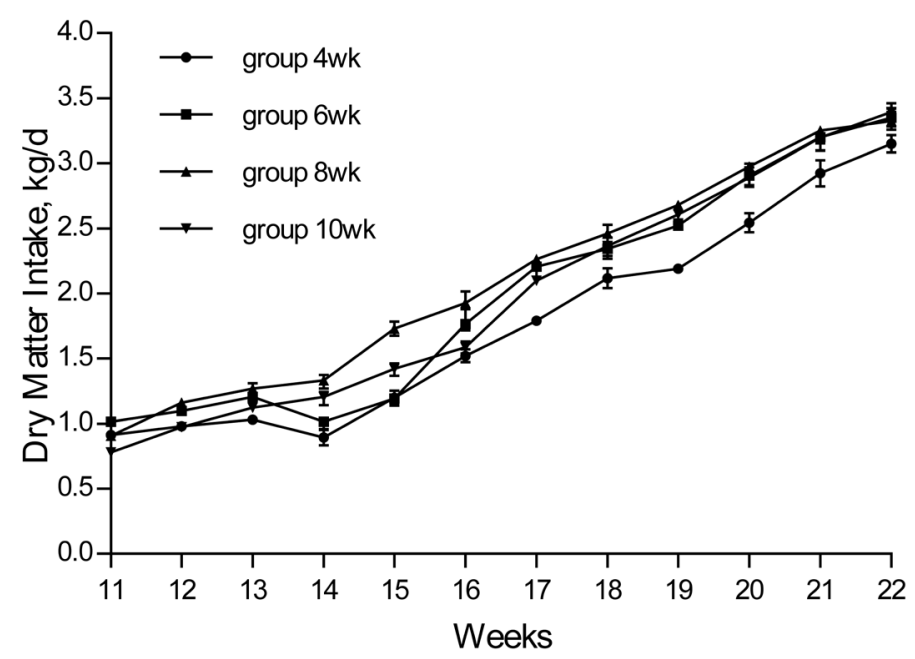

Figure 3. Effect of weaning age on dry matter intake from 11 wk to 22 wk was shown as means \pm standard errors. Control group not shown. 
Table 2. Effect of weaning age on growth performance and body size of calves

\begin{tabular}{|c|c|c|c|c|c|c|c|}
\hline Item & Control group & Group 4 wk & Group 6 wk & Group 8 wk & Group 10 wk & SEM & p-value \\
\hline \multicolumn{8}{|c|}{ Feed efficiency (BW gain divided by intake of MR, starter and hay) } \\
\hline $11-13 w k$ & - & $0.536^{\mathrm{a}}$ & $0.509^{\mathrm{a}}$ & $0.451^{b}$ & $0.445^{b}$ & 0.034 & 0.039 \\
\hline $14-22$ wk & - & $0.414^{\mathrm{a}}$ & $0.412^{\mathrm{a}}$ & $0.405^{\mathrm{ab}}$ & $0.381^{b}$ & 0.0173 & 0.021 \\
\hline \multicolumn{8}{|l|}{ Body weight (kg) } \\
\hline Initial & 34.00 & 33.25 & 32.25 & 35.17 & 33.46 & 0.737 & 0.274 \\
\hline $10 w k(70 d)$ & $76.75^{b}$ & $65.20^{c}$ & $71.55^{c}$ & $79.58^{\mathrm{a}}$ & $77.67^{b}$ & 1.515 & 0.0005 \\
\hline Total gain & $99.63^{\mathrm{a}}$ & $92.15^{b}$ & $102.50^{\mathrm{a}}$ & $101.08^{\mathrm{a}}$ & $100.17^{a}$ & 2.307 & 0.042 \\
\hline \multicolumn{8}{|l|}{$A D G(\mathrm{~kg} / \mathrm{d})$} \\
\hline 1-10 wk & $0.61^{\mathrm{a}}$ & $0.46^{b}$ & $0.56^{b}$ & $0.63^{\mathrm{a}}$ & $0.63^{\mathrm{a}}$ & 0.031 & 0.031 \\
\hline $11-13$ wk & 0.62 & 0.58 & 0.60 & 0.60 & 0.62 & 0.026 & 0.076 \\
\hline $14-22$ wk & $0.73^{b}$ & $0.75^{\mathrm{b}}$ & $0.85^{\mathrm{a}}$ & $0.74^{b}$ & $0.73^{b}$ & 0.036 & 0.041 \\
\hline Total gain & 40.06 & 39.30 & 39.04 & 40.04 & 39.33 & 0.527 & 0.963 \\
\hline \multicolumn{8}{|c|}{ Wither height $(\mathrm{cm})$} \\
\hline Initial & 65.06 & 63.5 & 64.4 & 64.65 & 63.25 & 0.645 & 0.815 \\
\hline Final & $93.65^{\mathrm{a}}$ & $89.63^{b}$ & $89.58^{b}$ & $92.32^{\mathrm{a}}$ & $93.37^{\mathrm{a}}$ & 0.542 & 0.024 \\
\hline Total gain & $28.59^{\mathrm{ab}}$ & $26.13^{c}$ & $25.18^{c}$ & $27.67^{b c}$ & $30.12^{\mathrm{a}}$ & 0.541 & 0.027 \\
\hline \multicolumn{8}{|l|}{ Heart girth $(\mathrm{cm})$} \\
\hline Initial & 76.05 & 74.9 & 75.04 & 74.47 & 75.24 & 0.677 & 0.957 \\
\hline Final & 119.85 & 113.29 & 114.94 & 117.15 & 118.79 & 0.818 & 0.062 \\
\hline Total gain & 43.80 & 38.39 & 39.90 & 42.68 & 43.55 & 0.805 & 0.127 \\
\hline \multicolumn{8}{|c|}{ Abdominal circumference $(\mathrm{cm})$} \\
\hline Initial & 79.02 & 77.55 & 77.95 & 78.14 & 78.57 & 0.660 & 0.613 \\
\hline
\end{tabular}

SEM, standard error of the mean; BW, body weight; MR, milk replacer; $A D G$, average daily gain.

a-c Within a row, means with different superscripts differ $(p<0.05)$.

0.05). In the second period, digestibility of DM and OM was higher in the group $4 \mathrm{wk}$ and group $6 \mathrm{wk}$ than that in the group 8 wk and group $10 \mathrm{wk}(\mathrm{p}<0.05)$ (Table 3$)$.

\section{Blood-biochemical parameters}

Concentration of the blood glucose of calves at age of $10 \mathrm{wk}$, $13 \mathrm{wk}$, and $22 \mathrm{wk}$ in group $4 \mathrm{wk}$, group $6 \mathrm{wk}$, group $8 \mathrm{wk}$, and group $10 \mathrm{wk}$ was less than that in the control group $(\mathrm{p}<0.05)$. Concentration of blood urea nitrogen (BUN) of calves at age of $10 \mathrm{wk}$ in group $10 \mathrm{wk}$ had no significant difference with the control group but greater than that in the group $4 \mathrm{wk}, 6 \mathrm{wk}$, and $8 \mathrm{wk}$. Concentration of BUN of calves at age of $13 \mathrm{wk}$ and $22 \mathrm{wk}$ in group $4 \mathrm{wk}$, group $6 \mathrm{wk}$, group $8 \mathrm{wk}$ and group $10 \mathrm{wk}$ were less than that in the control group $(\mathrm{p}<0.05)$. Concentration of blood total protein, globulin and albumin, IgG, IgA, IgM, and ALP had no significant difference among the groups (p>0.05) (Table 4).

\section{DISCUSSION}

Intake

DMI of calves in group $4 \mathrm{wk}$ and $6 \mathrm{wk}$ decreased and DMI of calves in group $8 \mathrm{wk}$ increased less at wk 14 when they just weaned off the MR, which might give them weaning stress, but the calves in group $10 \mathrm{wk}$ and control group were not affected. Starter intake of calves in group 4 wk was significantly higher than that in group $6 \mathrm{wk}$, group $8 \mathrm{wk}$, group $10 \mathrm{wk}$, and control group at wk 6 and wk $7(\mathrm{p}<0.05)$. The MR feeding could increase the consumption of starter as the amount of MR consumption increased [14]. DMI of calves in group $4 \mathrm{wk}$ was lower than that in the rest groups from wk 14 to wk 22, and calves weaned off dam's milk at early age of 4 weeks and fed 
Table 3. Effect of weaning age on nutrients apparent digestibility (\%) by calves in two periods

\begin{tabular}{lcccccc}
\hline Apparent digestibility (\%) & Group 4 wk & Group 6 wk & Group 8 wk & Group 10 wk & SEM & p-value \\
\hline 12 wk (87-90 d) & & & & & & \\
DM & 78.36 & 78.54 & 75.53 & 76.13 & 0.603 & 0.180 \\
OM & 79.20 & 78.98 & 77.88 & 77.26 & 0.515 & 0.336 \\
CP & 68.23 & 69.82 & 67.43 & 67.50 & 0.978 & 0.268 \\
EE & 70.65 & 72.26 & 67.26 & 71.00 & 1.327 & 0.076 \\
Ca & 53.25 & 60.08 & 61.71 & 62.66 & 1.941 & 0.158 \\
P & 74.21 & 75.13 & 70.33 & 76.69 & 1.797 & 0.062 \\
21 wk (147-150 d) & & & & & & \\
DM & $77.32^{\mathrm{a}}$ & $78.50^{\mathrm{a}}$ & $73.03^{\mathrm{b}}$ & $70.28^{\mathrm{b}}$ & 1.152 & 0.048 \\
OM & $79.97^{\mathrm{a}}$ & $80.96^{\mathrm{a}}$ & $76.11^{\mathrm{b}}$ & $74.23^{\mathrm{b}}$ & 0.963 & 0.043 \\
CP & 70.21 & 72.60 & 69.11 & 67.50 & 1.189 & 0.242 \\
EE & 61.74 & 69.65 & 63.74 & 68.48 & 3.262 & 0.105 \\
Ca & 61.37 & 57.10 & 57.17 & 56.64 & 1.471 & 0.174 \\
P & 70.31 & 70.33 & 65.84 & 61.24 & 1.662 & 0.082 \\
\hline
\end{tabular}

SEM, standard error of the mean; $D M$, dry matter; $\mathrm{OM}$, organic matter; $\mathrm{CP}$, crude protein; $\mathrm{EE}$, ether extract.

${ }^{a-b}$ Within a row, means with different superscripts differ $(p<0.05)$.

on MR was detrimental for calves with lower BW (125.4 \pm 2.5 $\mathrm{kg})$ and weight gain $(92.15 \pm 2.30 \mathrm{~kg})$ in the long term. It is reported that Shorthorn cattle weaned early as $123 \mathrm{~d}$ had no significant difference of feed efficiency with those weaned conventionally at $259 \mathrm{~d}$ [15]. In our study, calves weaned at 8 wk and 10 wk had no significant difference of feed efficiency with those weaned after $22 \mathrm{wk}$, but calves weaned at $4 \mathrm{wk}$ and 6 wk had significant higher feed efficiency than calves in group $8 \mathrm{wk}$ and $10 \mathrm{wk}$ in 11 to $13 \mathrm{wk}$, and calves weaned off at $4 \mathrm{wk}$ and $6 \mathrm{wk}$ had significant higher feed efficiency with those in group $10 \mathrm{wk}$ in 14 to $22 \mathrm{wk}$, but no significant difference with calves in group $8 \mathrm{wk}$. Collectively, weaning calves as early as 4 or 6 weeks age increased their feed efficiency.

\section{Weight gain and body size measurements}

Calves in group $6 \mathrm{wk}$ had lower BW at age of $10 \mathrm{wk}$ and $13 \mathrm{wk}$ but had no difference in final BW and total gain. Total gain of calves in group $4 \mathrm{wk}$ was significantly lower than that in control group, group $6 \mathrm{wk}, 8 \mathrm{wk}$, and $10 \mathrm{wk}$, which might be caused by the lower DMI of calves in group $4 \mathrm{wk}$ from wk 17 to wk 22. Body weight has a close relationship with body size [16] mainly with the heart girth [17]. And the body length, wither height and heart girth also show a close relation with the growth and development of the bone [18]. But in the present study, heart girth of calves had no significant difference among groups. Calves in group $4 \mathrm{wk}(89.63 \pm 0.5 \mathrm{~cm})$ and group $6 \mathrm{wk}(89.58$ $\pm 0.5 \mathrm{~cm}$ ) had lower wither height than that in control group $(93.65 \pm 0.5 \mathrm{~cm})$, group $8 \mathrm{wk}(92.32 \pm 0.5 \mathrm{~cm})$ and group $10 \mathrm{wk}$ $(93.37 \pm 0.5 \mathrm{~cm})$ at wk $22(\mathrm{p}<0.05)$, but hip width of calves in group $4 \mathrm{wk}(25.70 \pm 0.8 \mathrm{~cm})$ and group $6 \mathrm{wk}(25.45 \pm 0.8 \mathrm{~cm})$ had no significant difference with calves in control group (24.97 \pm $0.8 \mathrm{~cm})$ and group $8 \mathrm{wk}(25.70 \pm 0.8 \mathrm{~cm})$, and was lower than that in group $10 \mathrm{wk}(23.83 \pm 0.8 \mathrm{~cm})$ at $\mathrm{wk} 22(\mathrm{p}>0.05)$, calves amount might be not enough to get the relationship between body size and BW.

\section{Nutrients digestibility}

In the second measurement period (21 wk), higher digestibility of DM and OM of calves in group $4 \mathrm{wk}$ and group $6 \mathrm{wk}$ might be a compensatory for reaction of nutrient caused by early weaning. And it is consistent with that ADG of calves in group $4 \mathrm{wk}$ and $6 \mathrm{wk}$ from 13 to $22 \mathrm{wk}$ are significantly higher than that in control group, group $8 \mathrm{wk}$ and group $10 \mathrm{wk}$. Low nutrition digestibility might be induced by reduced rumen development and microbial function [19]. Weaning before 8 wk then fed on MR, the calves had higher intake of starter, which might induce the rumen development and microbial population. It is reported that high starter DMI was associated with low nutrient digestibility due to a high passage rate [20], but starter and hay DMI were higher in the calves of group $4 \mathrm{wk}$ and group $6 \mathrm{wk}$ in the present study, and no significant difference of digestibility was found between the groups in the first measurement period ( $12 \mathrm{wk}$ ) and significant difference of digestibility was higher in the second measurement period, which was consistent with the result that weaned at 28 $\mathrm{d}$ or $42 \mathrm{~d}$ of age had no reductions in intake or digestion compared with calves fed conventional MR and gained as much total BW from $0-84 \mathrm{~d}$ as calves stepped up to $1.09 \mathrm{~kg}$ of $\mathrm{MR}$ [21]. After the $17 \mathrm{~W}$, the DMI was lower in the group $4 \mathrm{wk}$ than that in the rest groups, and also feed efficiency and ADG was less than that in group $6 \mathrm{wk}$.

\section{Blood-biochemical parameters}

Serum parameters represent an integrated index of nutrient supply in relation to the utilization of nutrients.

It was reported that reduction in glucose concentration with 
Table 4. Effect of weaning age on blood-biochemical parameters and immune biomarkers of calves

\begin{tabular}{|c|c|c|c|c|c|c|c|c|c|}
\hline \multirow{2}{*}{ Item } & \multirow{2}{*}{ Control group } & \multirow{2}{*}{ Group 4 wk } & \multirow{2}{*}{ Group 6 wk } & \multirow{2}{*}{ Group 8 wk } & \multirow{2}{*}{ Group 10 wk } & \multirow{2}{*}{ SEM } & \multicolumn{3}{|c|}{$p$-value } \\
\hline & & & & & & & $\mathrm{Tr}$ & Age & Tr $\times$ Age \\
\hline \multicolumn{10}{|l|}{ Glucose (mmol/L) } \\
\hline 13 wk (91 d) & $7.26^{\mathrm{a}}$ & $5.57^{\mathrm{b}}$ & $5.59^{b}$ & $5.11^{b}$ & $5.89^{\mathrm{b}}$ & 0.101 & 0.023 & - & - \\
\hline $22 w k(150 d)$ & $6.11^{\mathrm{a}}$ & $5.65^{b}$ & $5.41^{b}$ & $5.74^{b}$ & $5.66^{b}$ & 0.294 & 0.041 & - & - \\
\hline \multicolumn{10}{|c|}{ Urea nitrogen (mmol/L) } \\
\hline 13 wk (91 d) & $5.67^{\mathrm{a}}$ & $4.19^{b}$ & $4.34^{b}$ & $4.41^{b}$ & $4.51^{b}$ & 0.552 & 0.029 & - & - \\
\hline 22 wk (150d) & $5.58^{\mathrm{a}}$ & $4.20^{b}$ & $4.27^{b}$ & $4.11^{\mathrm{b}}$ & $4.55^{b}$ & 0.351 & 0.006 & - & - \\
\hline \multicolumn{10}{|l|}{ Total protein (g/L) } \\
\hline 10 wk (70 d) & 44.79 & 36.70 & 43.69 & 42.60 & 43.59 & 3.145 & 0.689 & 0.174 & 0.463 \\
\hline 13 wk (91 d) & 42.34 & 42.01 & 46.36 & 42.23 & 42.61 & 4.257 & 0.753 & - & - \\
\hline 22 wk (150 d) & 31.09 & 30.84 & 31.79 & 32.32 & 31.11 & 3.258 & 0.964 & - & - \\
\hline \multicolumn{10}{|l|}{ Globulin (g/L) } \\
\hline 10 wk (70 d) & 12.25 & 9.85 & 10.71 & 9.69 & 11.37 & 2.333 & 0.265 & 0.862 & 0.638 \\
\hline 13 wk (91 d) & 9.79 & 10.37 & 12.13 & 11.58 & 13.19 & 1.672 & 0.297 & - & - \\
\hline 22 wk (150 d) & 10.42 & 12.95 & 9.95 & 10.86 & 11.32 & 1.505 & 0.353 & - & - \\
\hline \multicolumn{10}{|l|}{$\lg G(g / L)$} \\
\hline 10 wk (70 d) & 9.49 & 8.03 & 7.00 & 8.36 & 10.39 & 0.727 & 0.337 & 0.295 & 0.308 \\
\hline 13 wk (91 d) & 8.45 & 8.65 & 7.30 & 8.77 & 8.84 & 0.809 & 0.851 & - & - \\
\hline 22 wk (150 d) & 8.69 & 9.88 & 9.14 & 9.45 & 10.09 & 0.377 & 0.439 & - & - \\
\hline \multicolumn{10}{|l|}{$\operatorname{lgM}(g / L)$} \\
\hline \multicolumn{10}{|l|}{$\operatorname{ALP}(U / L)$} \\
\hline 10 wk (70 d) & 341.84 & 436.41 & 462.06 & 370.95 & 372.79 & 28.385 & 0.208 & 0.935 & 0.726 \\
\hline 13 wk (91 d) & 410.52 & 457.15 & 415.10 & 361.20 & 382.03 & 25.787 & 0.140 & - & - \\
\hline $22 w k(150 d)$ & 404.65 & 405.53 & 426.23 & 427.03 & 435.39 & 34.230 & 0.391 & - & - \\
\hline
\end{tabular}

SEM, standard error of the mean; Tr, treatment; IgG, immunoglobulin G; ALP, alkaline phosphatase.

${ }^{\mathrm{a}-\mathrm{c}}$ Within a row, means with different superscripts differ $(p<0.05)$.

age was mostly caused by reducing milk provision [22], in the present study, the amount of MR fed to calves in the 4 groups was less than the amount of milk calves suckled in control group, which might induce less glucose in the calves of the 4 groups than that in control group, of which the glucose decreased at the end of experiment. It is reported that lambs weaned at $10 \mathrm{~d}$ had lower glucose because of better developed rumens [23]. Serum glucose concentration was lower in the calves fed on MR than those in control groups, which might be induced by the increased intake of starter, and also blood glucose decreases with age and development of ruminant function [24]. With the development of rumen, the neonatal calves become dependent on the products of rumen fermentation and volatile fatty acids become their main energy source $[25,26]$. Calves fed on MR early had higher and earlier starter intake and lower glucose, possibly indicating that rumen development [27].

BUN is the marker of the conditions of protein metabolism and dietary amino acid balance in the animal [28]. Concentration of BUN was higher in control group and group $10 \mathrm{wk}$ than those in the other treatment groups at $70 \mathrm{~d}$, higher in control group than those in the treatment groups at $84 \mathrm{~d}$ and had no difference in the 5 groups at the end of the experiment. As starter intake increased in each treatment group, the concen- 
tration of BUN decreased. Fresh milk contained more protein (27\%, dry matter basis) than the MR (23.94\%, dry matter basis), new weaning calves in group $10 \mathrm{wk}$ and calves in control group had higher BUN than those in the other treatment groups at $70 \mathrm{~d}$, the same as higher BUN in calves of control group at $84 \mathrm{~d}$. When the calves no longer had an intake of milk in control group at the end of the trial, there was no difference in BUN. With an increase in starter intake, BUN decreased in each treatment group. It is reported that higher CP intake might induce higher levels of BUN [29,30]. Preweaning MR program had no effect on the $\mathrm{CP}$ intake when they received the same feed after weaning.

The concentration of total protein, albumin, globulin IgG, IgA, and IgM were in the normal range, which indicates that the animals were in healthy status and the treatments no adverse effect on their performance [31].

ALP is sometimes used as markers of bone growth [1]. In the present study, calves in control group, group $8 \mathrm{wk}$, and group $10 \mathrm{wk}$ had higher wither height $(\mathrm{p}<0.05)$ and calves in group $4 \mathrm{wk}$ and $6 \mathrm{wk}$ had higher hip width, which was consistent with the result of the ALP concentration in blood.

A series of studies conducted by our labs proved that feeding lambs on MR could cut the costs of feeding and spare the ewes for next breeding without affecting the performance of lambs [23]. Early weaning of beef calves is a management method that could be used when extra benefits outweigh the extra labor cost and other expense. As a part of the studies, we will take cost of MR, labor, feeding facilities and cows' physical changes and nutrition demands into consideration in the further study.

\section{CONCLUSION}

Early weaning increased the consumption of the MR and starters in beef calves, which could reduce the cost on the feeding and bring more profitability. The present study shows that calves could be weaned off the dam's milk at 4 weeks, but the optimal age to switch them to MR from suckling was at 6 weeks of age. Further study should be focused on the physical changes and the nutrition demands of cows with early weaning calves and the pre- and post-weaning nutritional management of early weaning calves.

\section{CONFLICT OF INTEREST}

We certify that there is no conflict of interest with any financial organization regarding the material discussed in the manuscript.

\section{ACKNOWLEDGMENTS}

This work was supported by "Young Herbivorous Livestock
Rearing Technology Research in Southern China (No. 2013 03143)", Special Fund for Agro-scientific Research in Public Interest from Ministry of Agriculture.

\section{REFERENCES}

1. Zezeski AL, McCracken VL, Poole RK, et al. Metabolic and reproductive characteristics of replacement beef heifers subjected to an early-weaning regimen involving high-concentrate feeding. Animal 2017;11:820-5.

2. Marshall CM, Walker AP. Comparison of a short method for kjeldahl digestion using a trace of selenium as catalyst, with other methods. J Sci Food Agric 1978;87:3429-50.

3. Blanco M, Ripoll G, Albertí P, et al. Effect of early weaning on performance, carcass and meat quality of spring-born bull calves raised in dry mountain areas. Livest Sci 2008;115:226-34.

4. Wertz AE, Berger LL, Walker PM, et al. Early-weaning and postweaning nutritional management affect feedlot performance, carcass merit, and the relationship of 12th-rib fat, marbling score, and feed efficiency among Angus and Wagyu heifers. J Anim Sci 2002;80:28-37.

5. Myers SE, Faulkner DB, Ireland FA, Parrett DF. Comparison of three weaning ages on cow-calf performance and steer carcass traits. J Anim Sci 1999;77:323-9.

6. Vaz RZ, Lobato J. Effects of the weaning age of calves on somatic development and on reproductive performance of beef cows. Rev Bras Zootec 2010;39:1058-67.

7. Odhiambo JF, Rhinehart JD, Helmondollar R, et al. Effect of weaning regimen on energy profiles and reproductive performance of beef cows. J Anim Sci 2009;87:2428-36.

8. Kehoe SI, Dechow CD, Heinrichs AJ. Effects of weaning age and milk feeding frequency on dairy calf growth, health and rumen parameters. Livest Sci 2007;110:267-72.

9. Waterman RC, Geary TW, Paterson JA, Lipsey RJ. Early weaning in Northern Great Plains beef cattle production systems: II. Development of replacement heifers weaned at 80 or 215 d of age. Livest Sci 2012;148:36-45.

10. Lesmeister KE, Heinrichs AJ. Effects of corn processing on growth characteristics, rumen development, and rumen parameters in neonatal dairy calves. J Dairy Sci 2004;87:3439-50.

11. Horwitz W, Latimer G. Official methods of analysis of AOAC International. Gaithersburg, MD, USA: AOAC International; 2006.

12. Van Soest PJ, Robertson JB, Lewis BA. Methods for dietary fiber, neutral detergent fiber, and nonstarch polysaccharides in relation to animal nutrition. J Dairy Sci 1991;74:3583-97.

13. Goering HK, Van Soest PJ. Forage fiber analyses. In: Apparatus, reagents, procedures, and some applications. Washington DC, USA: Agriculture handbook; 1970.

14. Jasper J, Weary DM. Effects of ad libitum milk intake on dairy calves. J Dairy Sci 2002;85:3054-58.

15. Wolcott ML, Graser HU, Johnston DJ. Effects of early weaning 
on growth, feed efficiency and carcass traits in Shorthorn cattle. Anim Prod Sci 2010;50:315-21.

16. Heinrichs AJ, Rogers GW, Cooper JB. Predicting body weight and wither height in Holstein heifers using body measurements. J Dairy Sci 1992;75:3576-81.

17. Heinrichs AJ, Erb HN, Rogers GW, Cooper JB, Jones CM. Variability in Holstein heifer heart-girth measurements and comparison of prediction equations for live weight. Prev Vet Med 2007;78:333-8.

18. Wickersham E, Schultz L. Influence of age at first breeding on growth, reproduction, and production of well-fed Holstein Heifers. J Dairy Sci 1963;46:544-9.

19. Terré M, Devant M, Bach A. Effect of level of milk replacer fed to Holstein calves on performance during the preweaning period and pellet. Livest Sci 2007;110:82-8.

20. Seo S, Tedeschi LO, Schwab CG, Garthwaite BD, Fox DG. Evaluation of the passage rate equations in the 2001 Dairy NRC model. J Dairy Sci 2006;89:2327-42.

21. Hill TM, Bateman HN, Aldrich JM, Schlotterbeck RL. Effect of milk replacer program on digestion of nutrients in dairy calves. J Dairy Sci 2010;93:1105-15.

22. Quigley JR, Caldwell LA, Sinks GD, Heitmann RN. Changes in blood glucose, nonesterified fatty acids, and ketones in response to weaning and feed intake in young calves. J Dairy Sci 1991;74:250-7.

23. Chai JM, Ma T, Wang HC, et al. Effect of early weaning age on growth performance, nutrient digestibility, and serum parameters of lambs. Anim Prod Sci 2017;57:110-5.

24. Hugi D, Blum JW. Changes of blood metabolites and hormones in breeding calves associated with weaning. Transbound Emerg Dis 1997;44:99-108.

25. Khan MA, Lee HJ, Lee WS, et al. Structural growth, rumen development, and metabolic and immune responses of Holstein male calves fed milk through step-down and conventional methods. J Dairy Sci 2007;90:3376-87.

26. Paez Lama S, Grilli D, Egea V, et al. Rumen development and blood metabolites of Criollo kids under two different rearing systems. Livest Sci 2014;167:171-7.

27. Cheema AT, Bhatti SA, Akbar G, et al. Effect of weaning age and milk feeding level on pre- and post-weaning growth performance of Sahiwal calves. Anim Prod Sci 2016;58:314-21.

28. Blome RM, Drackley JK, McKeith FK, Hutjens MF, McCoy GC. Growth, nutrient utilization, and body composition of dairy calves fed milk replacers containing different amounts of protein. J Anim Sci 2003;81:1641-55.

29. Khan MA, Lee HJ, Lee WS, et al. Pre- and postweaning performance of holstein female calves fed milk through step-down and conventional methods. J Dairy Sci 2007;90:876-85.

30. Bahrami-yekdangi M, Ghorbani GR, Khorvash M, Khan MA, Ghaffari MH. Reducing crude protein and rumen degradable protein with a constant concentration of rumen undegradable protein in the diet of dairy cows: Production performance, nutrient digestibility, nitrogen efficiency, and blood metabolites. J Anim Sci 2016;94:718-25.

31. Radostits O, Gay C, Hinchcliff K, Constable P. Veterinary medicine. A textbook of the diseases of cattle, sheep, pigs goats and horses. London, UK: W.B. Saunders Ltd; 2007. 